\title{
DAMPAK SELF-EFFICACY TERHADAP KEMAMPUAN KOMUNIKASI MATEMATIS SISWA
}

\author{
Nurhanurawati $^{1 *}$, Widyastuti' ${ }^{2}$, Riyan Ramadhan ${ }^{3}$ \\ ${ }^{1,2,3}$ Prodi Pendidikan Matematika Fakultas Keguruan dan Ilmu Pendidikn, Universitas Lampung \\ Jalan Prof. Dr. Soemantri Brojonegoro No 1, Bandarlampung, Indonesia \\ e-mail: ${ }^{1}$ nurha.nurawati@ fkip.unila.ac.id; ${ }^{2}$ widyastuti.1986@fkip.unila.ac.id; \\ Submitted: March 20, 2021 \\ Revised: June 2, 2021 \\ Accepted: July 16, 2021 \\ corresponding author*
}

\begin{abstract}
Abstrak
Penelitian ini bertujuan untuk mengetahui dan mendeskripsikan pengaruh self-efficacy terhadap kemampuan komunikasi matematis siswa. Populasi dalam penelitian adalah seluruh siswa kelas IX SMP Negeri 20 Bandar Lampung tahun pelajaran 2020/2021 yang terdistribusi dalam sepuluh kelas. Sampel penelitian ini adalah siswa kelas IX F sebanyak 30 siswa yang dipilih menggunakan teknik cluster random sampling. Desain yang digunakan adalah desain penelitian kausal komparatif. Data penelitian ini berupa data kuantitatif yang diperoleh dari pengisian instrumen angket self-efficacy dan tes kemampuan komunikasi matematis yang merupakan data primer. Teknik analisis data yang digunakan dalam penelitian ini adalah regresi linier sederhana dengan $\alpha=0,05$. Hasil penelitian menunjukkan bahwa mayoritas siswa memiliki kemampuan komunikasi matematis dan self-efficacy yang cukup tinggi dan semakin tinggi self-efficacy siswa maka kemampuan komunikasi matematis siswa juga semakin tinggi. Kesimpulan dari penelitian ini adalah self-efficacy siswa memiliki pengaruh positif yang signifikan terhadap kemampuan komunikasi matematis siswa, dengan 63,1\% variabilitas kemampuan komunikasi siswa dapat dijelaskan oleh self-efficacy.
\end{abstract}

Kata Kunci: komunikasi matematis, self-efficacy

\section{SELF-EFFICACY: THE IMPACT ON STUDENTS' MATHEMATICAL COMMUNICATION ABILITY}

\begin{abstract}
The aim of this research is to describe the effect of students' self-efficacy on students' mathematical communication skills. The population were all grade 9th students of SMP Negeri 20 Bandarlampung in academic year 2020/2021, which were distributed in ten classes. The sample of this research consists of 30 students who were selected using cluster random sampling technique. The design used in this research is a comparative causal research design. The research data obtained from the use of self-efficacy scale and tests of mathematical communication skills which are primary data. The data analysis technique used in this study is simple linear regression with $\alpha=0.05$. The results showed that most of the students had high cathegory of mathematical communication skills and self-efficacy, and also the higher students' selfefficacy, the higher students' mathematical communication skills. The conclusion of this research is that student self-efficacy has a significant positive effect on students' mathematical communication skills, with $63.1 \%$ variability of students' mathematical communication skills affected by self-efficacy.
\end{abstract}

Keywords: mathematical communication, self-efficacy

\section{Pendahuluan}

Pendidikan merupakan kebutuhan mutlak bagi kehidupan manusia untuk membentuk kepribadian (Inanna, 2018), sehingga harus dipenuhi sepanjang hayat. Tanpa pendidikan, suatu kelompok masyarakat tidak dapat hidup berkembang sejalan dengan aspirasi (cita-cita) untuk maju, sejahtera dan bahagia menurut konsep pandangan hidup mereka (Ihsan, 2011). Hal ini juga disebutkan dalam Undang-Undang No 20 Tahun 2003 pasal 3 bahwa, pendidikan berfungsi mengembangkan dan membentuk watak serta peradaban bangsa dalam rangka mencerdaskan kehidupan bangsa.

Pendidikan dapat ditempuh baik secara formal, non formal maupun informal. Pada pendidikan formal, matematika merupakan salah satu mata pelajaran yang penting diajarkan di sekolah. Matematika merupakan alat dan pelayan terhadap ilmu lain, artinya matematika tumbuh dan berkembang untuk dirinya sendiri sebagai ilmu dan pelayan untuk ilmu lain dan juga untuk memenuhi kebutuhan ilmu pengetahuan dalam pengembangan dan operasionalnya (Noer, 2012).

Copyright $(\odot$ Authors. This is an open access article distributed under the Attribution-NonCommercial-

ShareAlike 4.0 International (CC BY-NC-SA 4.0), which permits unrestricted use, distribution, and reproduction in any medium, provided the original work is properly cited. 
Matematika berperan penting dalam mendukung perkembangan pribadi dari berbagai aspek seperti sosial, ekonomi, dan teknologi, arsitektur, dan sebagainya (Hodanova \& Nocar, 2016). Pentingnya matematika ditegaskan dalam peraturan menteri pendidikan dan kebudayaan Republik Indonesia No 70 Tahun 2018 yang menggolongkan matematika sebagai mata pelajaran wajib dengan alokasi waktu 5 jam pelajaran pada setiap minggunya. Tujuan pembelajaran matematika dalam Permendikbud Nomor 36 Tahun 2018 adalah agar peserta didik mempunyai kemampuan untuk memahami konsep matematika, menggunakan penalaran, memecahkan masalah, mengomunikasikan gagasan dengan simbol, tabel, diagram atau media lain untuk memperjelas keadaan atau masalah serta memiliki sikap menghargai kegunaan matematika dalam kehidupan. Untuk mencapai tujuan pembelajaran matematika, salah satu kemampuan yang harus dikuasai siswa adalah kemampuan komunikasi matematis.

Kemampuan komunikasi matematis adalah kemampuan menyampaikan gagasan atau ide matematik baik secara lisan maupun tertulis serta kemampuan memahami dan menerima gagasan atau ide matematik orang lain secara cermat, analitis, kritis, evaluatif untuk mempertajam pemahaman (Lestari dan Yudhanegara, 2015). Terkait dengan hal ini Astuti dan Leonard (2015) berpendapat bahwa, kemampuan komunikasi matematis adalah kemampuan peserta didik untuk mempresentasikan permasalahan atau ide dalam matematika dengan menggunakan benda nyata, gambar, grafik, atau tabel, serta dapat menggunakan simbol-simbol matematika. Sedangkan Cai, Lane, dan Jacobsin (Fachrurazi, 2011) menyatakan bahwa, kemampuan komunikasi matematis siswa terbagi menjadi tiga kelompok, yaitu: (1) menulis matematis (written texts), siswa dituntut untuk dapat menuliskan penjelasan secara matematis, masuk akal, jelas serta tersusun secara logis, (2) menggambar secara matematis (drawing), siswa dituntut untuk dapat melukiskan gambar, diagram, dan tabel secara lengkap dan benar; dan (3) ekspresi matematika (mathematical expression), siswa mampu untuk memodelkan permasalahan matematis secara benar sehingga perhitungan mendapatkan solusi secara lengkap dan benar.

Namun demikian, aspek kognitif terkait kemampuan komunikasi matematis bukan merupakan satu-satunya hal penting yang harus dimiliki siswa. Dalam Undang-Undang No 20 Tahun 2003 pasal 3 tentang tujuan pendidikan nasional disebutkan bahwa, salah satu fungsi pendidikan nasional ialah membentuk watak serta peradaban bangsa yang bermartabat dalam rangka mencerdaskan kehidupan bangsa. Salah satu aspek yang perlu diperhatikan ialah self-efficacy. Bandura (1997) berpendapat bahwa Self-efficacy merupakan kepercayaan terhadap kemampuan yang dimiliki individu untuk mencapai tingkat kinerja yang diinginkan atau ditentukan. Noer (2012) juga mendefinisikan self-efficacy sebagai pendapat seseorang mengenai kemampuannya dalam melakukan suatu aktivitas tertentu. Lebih lanjut, Noer (2012) mengemukakan bahwa selfefficacy akan memengaruhi pilihan seseorang dalam pengaturan perilaku, banyaknya usaha mereka untuk menyelesaikan tugas, dan lamanya waktu mereka bertahan dalam menghadapi hambatan. Selain itu, Victoriana (2012) mengemukakan bahwa seseorang dengan selfefficacy yang tinggi akan memberikan upaya yang tinggi pada apa yang dikerjakannya dan meningkatkan upaya saat terjadi kegagalan atau kemunduran. Disebutkannya self-efficacy sebagai salah satu faktor yang memengaruhi besarnya suatu usaha terhadap suatu pekerjaan menunjukkan bahwa self-efficacy merupakan hal yang penting yang juga harus diperhatikan terlebih dalam belajar matematika.

Hasil Programme International for Student Assesment (PISA) tahun 2015 (OECD, 2018) menunjukkan bahwa rata-rata skor literasi matematika Indonesia menempati peringkat 64 dari 67 negara yang berpartisipasi dan memperoleh skor 386 sementara skor rata-rata yang ditetapkan Organisation for Economic Cooperation and Development (OECD) yaitu 490. Simalango, dkk (2018) dalam hasil penelitiannya menyebutkan bahwa dalam menyelesaikan soal PISA siswa kesulitan dalam memahami soal, membuat model matematika, menyelesaikan permasalahan matematika, dan menyimpulkan solusi. Hasil tersebut menunjukkan bahwa kemampuan siswa dalam bernalar, mengomunikasikan pengetahuan dan keterampilan matematikanya secara efektif siswa di Indonesia masih rendah. Rendahnya kemampuan dalam mengomunikasikan pengetahuan terutama dalam konteks matematis juga terjadi di SMP Negeri 20 Bandar Lampung. Berdasarkan jawaban yang diberikan siswa dalam menjawab soal ulangan harian materi sistem persamaan linier dua variable, diperoleh hasil bahwa siswa-siswa tersebut belum mampu membuat model matematika dari permasalahan yang diberikan sehingga siswa tidak dapat menyelesaikan masalah tersebut dengan benar. Hal tersebut menunjukkan bahwa kemampuan komunikasi siswa terutama dalam aspek mathematical expression masih rendah. 
Rendahnya kemampuan komunikasi matematis siswa dapat dipengaruhi oleh berbagai faktor. Berdasarkan hasil observasi dan wawancara dengan guru dan beberapa murid di SMP N 20 Bandar Lampung diperoleh bahwa usaha yang dilakukan oleh siswa cenderng kurang, banyak siswa yang menganggap matematika sangat sulit dan merasa dirinya tidak mampu menguasai matematika. Hal ini didukung oleh Siregar (2017) yang mengungkapkan bahwa matematika masih menjadi mata pelajaran yang dianggap sulit oleh kebanyakan siswa di Indonesia. Gewati (2018) juga mengungkapkan bahwa kebanyakan siswa di Indonesia menganggap matematika sebagai hal menakutkan yang tidak jarang membuat mereka mendapat nilai buruk dalam mata pelajaran tersebut. Cara pandang kebanyakan siswa di Indonesia terhadap matematika inilah yang menyebabkan kemampuan matematis siswa di Indonesia tergolong rendah.

Dalam belajar matematika banyak yang menganggap aspek yang perlu ditekankan hanya aspek kognitif saja, padahal pengembangan sikap merupakan bagian dari menyelesaikan mata pelajaran di sekolah (Hendriana, 2014). Hal ini diperkuat oleh pendapat Nuryani yang mengatakan bahwa seringkali penyebab siswa tidak mampu menunjukan hasil belajarnya secara optimal sesuai dengan kemampuan yang dimilikinya karena siswa merasa tidak yakin bahwa dirinya mampu menyelesaikan tugas-tugas yang dibebankan (Wulansari, dkk, 2019). Hasil penelitian Hendriana dan Kadarisma (2019) pada siswa SMP di Bandung mengungkapkan bahwa salah satu ranah afektif yang memengaruhi kemampuan komunikasi matematis ialah self-efficacy. Keyakinan akan kemampuan yang dimiliki akan membuat siswa memiliki dorongan lebih untuk berusaha menyelesaikan permasalahan yang diberikan, sehingga ikut memengaruhi kemampuan matematis siswa. Berdasarkan pemaparan diatas peneliti tertarik untuk melakukan penelitian yang bertujuan untuk melihat dampak dari self-efficacy terhadap kemampuan komunikasi matematis siswa.

\section{Metode Penelitian}

Penelitian ini dilaksanakan pada semester ganjil tahun pelajaran 2020/2021 di SMP Negeri 12 Bandarlampung. Populasi penelitian ini adalah semua siswa kelas IX yang terdistribusi menjadi sepuluh kelas yaitu kelas IX A sampai IX J. Pengambilan sampel dilakukan dengan teknik cluster rondom sampling sehingga terpilihlah kelas IX F dengan jumlah 30 siswa sebagai sampel penelitian.
Penelitian ini dilakukan menggunakan pendekatan deskriptif kuantitatif dengan variabel bebas adalah self-efficacy siswa, sedangkan variabel terikatnya adalah kemampuan komunikasi matematis siswa. Desain penelitian yang digunakan adalah penelitian kausal komparatif.

Data penelitian ini berupa data kuantitatif yaitu data self-efficacy siswa dan data kemampuan komunikasi matematis siswa yang merupakan data primer. Teknik pengumpulan data yang digunakan yaitu teknik tes untuk mengukur kemampuan komunikasi matematis dengan indikator yaitu writing, drawing, dan mathematical expression dan teknik non-tes untuk mengukur selfefficacy siswa. Instrumen tes berbentuk uraian yang terdiri dari empat butir soal topik bangun ruang sisi datar. Sedangkan instrumen non-tes yang digunakan adalah skala self-efficacy yang terdiri dari 18 butir pernyataan yang mencangkup tiga dimensi self-efficacy yaitu level, magnitude, dan strength dengan format respon jenis skala diferensial dengan interval jawaban 0 sampai 10.

Validitas instrumen pada penelitian ini didasarkan pada validitas isi melalui penilaian terhadap kesesuaian isi instrumen tes dengan kisi-kisi instrumen yang diukur dan kesesuaian bahasa yang digunakan dalam instrumen tes dengan kemampuan bahasa siswa yang dilakukan menggunakan daftar checklist $(\checkmark)$ oleh guru mitra mata pelajaran matematika kelas IX. Hasil validitas isi menunjukkan bahwa instrumen tes telah memenuhi validitas isi.

Hasil uji coba instrumen tes menunjukkan bahwa koefisien reliabilitas instrumen sebesar 0,77 dengan interpretasi reliabititas yang sangat tinggi (Arikunto, 2011), koefisien daya pembeda setiap butir berkisar antara 0,5 - 0,96 memiliki daya pembeda soal baik dan sangat baik serta indeks tingkat kesukaran setiap butir pada rentang 0,21 - 0,71 dengan interpretasi tingkat kesukaran sedang (Sudijono, 2013). Dengan demikian, instrumen tes tersebut layak digunakan untuk mengumpulkan data.

Hasil uji coba instrumen non-tes digunakan untuk melihat kelayakan instrumen melalui perhitungan validitas butir dan koefisien reliabilitas. Validitas non-tes yang digunakan berdasarkan korelasi product moment dengan angka kasar menggunakan rumus Pearson dengan interpretasi koefisien berdasarkan pendapat Arifin (2010). Berdasarkan hasil perhitungan, diperoleh koefisisen korelasi Pearson tiap butir berada pada interval 0,43 sampai 0,90 dengan interpretasi validitas sedang hingga sangat tinggi. Sedangkan koefisien reliabilitasnya sebesar 0,95 yang berarti instrumen non-tes yang digunakan memiliki reliabilitas yang sangat tinggi. Dengan demikian, disimpulkan bahwa instrumen non-tes yang digunakan layak untuk mengumpulkan data selfefficacy. 
Setelah diperoleh instrumen yang layak, kemudian dilakukan pengambilan data self-efficacy siswa dan dilanjutkan dengan pengumpulan data kemampuan komunikasi matematis siswa. Data yang diperoleh, dilolah secara deskriptif dan inferensial. Dilakukan juga kategorisasi self-efficacy dan kemampuan komunikasi matematis yang dimiliki siswa. Interpretasi kategori kemampuan komunikasi matematis siwa dan selfefficacy siswa ditentukan dengan menggunakan nilai $M i$ ((skor maksimum total + skor minimum total)/2) dan $S D i$ ((skor maksimum total - skor minimum total)/6). Jika adalah skor kemampuan kemampuan komunikasi matematis atau self-efficacy siswa. Maka kategori yang digunakan adalah sebagai berikut: (1) kategori sangat tinggi apabila $M i+1,5 S D i<x \leq M i+3 S D i$; (2) kategori tinggi apabila $M i+0,5 S D i<x \leq M i+$ 1.5SDi; (3) kategori sedang apabila $M i-0,5 S D i<$ $x \leq M i+0,5 S D i$; (4) kategori rendah apabila $M i-$ $1,5 S D i<x \leq M i-0,5 S D i$; (5) kategori sangat rendah apabila $M i-3 S D i \leq x<M i-1,5 S D i$ (Azwar, 2012).

Sebelum dilakukan uji hipotesis terlebih dahulu dilakukan uji prasyarat yaitu uji normalitas dan uji linieritas. Adapun uji normalitas data yang digunakan adalah Uji Kolmogorof Smirnov, sedangkan uji linieritas menggunakan Uji-F. Hasil uji pada $\alpha=5 \%$ menunjukkan bahwa data residual berasal dari populasi berdistribusi normal dan terdapat hubungan yang linier antara selfefficacy siswa dengan kemampuan komunikasi matematis siswa.

\section{Hasil dan Pembahasan}

Data kemampuan komunikasi matematis siswa diperoleh melalui tes secara online setelah pembelajaran dengan materi bangun ruang sisi datar. Diperoleh skor terendah siswa adalah 2 dan skor tertinggi siswa adalah 17. Kemampuan komunikasi matematis siswa tersebut kemudian dikelompokkan berdasarkan kriteria yang diadaptasi dari Azwar (2012). Persentase kategorisasi kemampuan komunikasi matematis siswa disajikan pada Gambar 1.

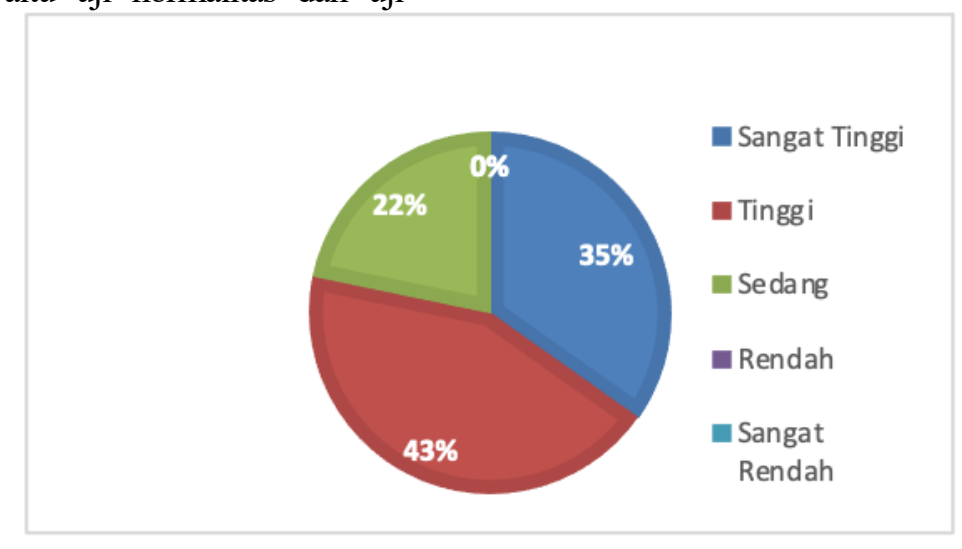

Gambar 1. Diagram persentase kategori kemampuan komunikasi matematis siswa

Berdasarkan Gambar 1, mayoritas siswa memiliki kemampuan komunikasi matematis dengan kategori tinggi. Persentase tertinggi kedua dimiliki oleh kategori kemampuan komunikasi matematis sangat tinggi serta tidak ada siswa dengan kategori kemampuan komunikasi matematis dengan kategori rendah dan sangat rendah. Hal ini menunjukkan bahwa mayoritas siswa sudah memiliki kemampuan komunikasi matematis yang baik.

Dari hasil pengisian angket self-efficacy yang mengukur dimensi level, magnitude, dan strength diperoleh skor terendah siswa adalah 38 dan nilai tertinggi siswa adalah 141. Kemudian rata-rata skor total self-efficacy 30 siswa adalah sebesar 94,6 dengan skor maksimum respon 180. Data skor total self-efficacy siswa tersebut kemudian dikelompokkan berdasarkan kriterianya untuk dibandingkan dengan data kemampuan komunikasi matematis siswa. Kriteria pengelompokkan self-efficacy siswa berdasarkan rumus yang dikutip dari acuan rumus yang diadopsi dari Azwar (2012) dengan hasil pengelompokkan yang disajikan pada Gambar 2. 


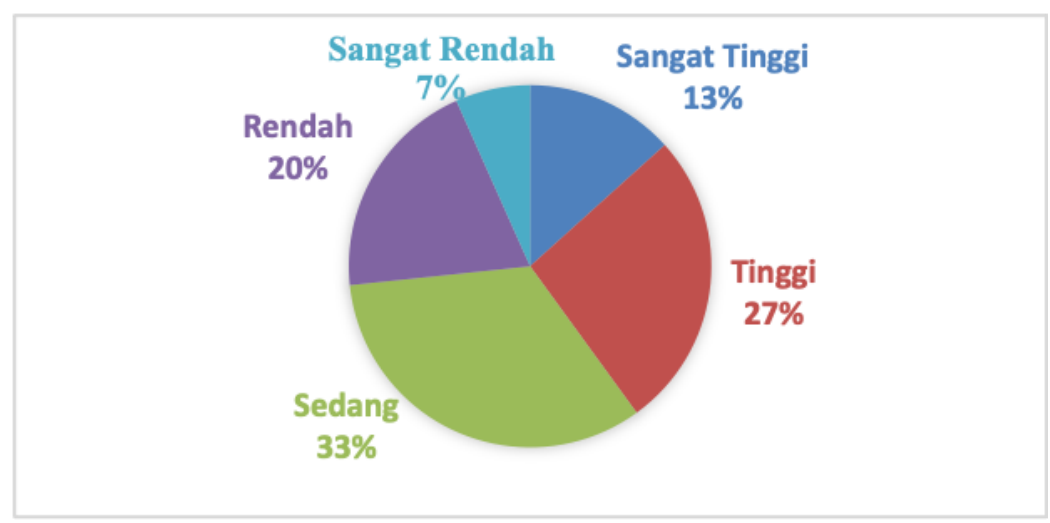

Gambar 2. Diagram persentase kategori self-efficacy siswa

Berdasarkan Gambar 2, diketahui bahwa hanya $27 \%$ siswa yang memiliki self-efficacy kurang optimal. Respon mayoritas yang diberikan siswa berada pada kategori self-efficacy sedang dan tinggi. Dengan kata lain, mayoritas siswa memiliki self-efficacy yang cukup tinggi. Walaupun demikian, hanya $13 \%$ siswa yang memiliki self-efficacy dengan kategori sangat tinggi.

Komparasi hasil analisis deskriptif kemampuan komuniksi matematis dan self-efficacy siswa memberikan hasil yang sejalan bahwa mayoritas siswa memiliki kemampuan komunikasi matematis dan selfefficacy yang tinggi. Artinya, terlihat adanya liniearitas antara kemampuan komunikasi matematis siswa dengan self-efficacy yang dimilikinya. Namun, hasil analisis juga menunjukkan adanya gap antara kedua variabel tersebut. Artinya, terdapat siswa dengan kemampuan komunikasi matematis yang baik namun memiliki self-efficacy yang rendah. Hal tersebut dimungkinkan terjadi, mengingat kultur budaya masyarakat di Indonesia seperti yang dikemukakan oleh Thackray (Mustaqim, 2009) bahwa kerendahan hati sebagai salah satu karakteristik budaya masyarakat Indonesia, seringkali menyebabkan suasana akademik menjadi kurang kompetitif, banyak orang yang enggan menunjukkan keyakinan atas kemampuan dirinya karena takut dianggap sombong.

Selanjutnya, karena data residual kemampuan komunikasi matematis dan self-efficacy berasal dari populasi yang berdistribusi normal dan terdapat hubungan yang linier antara self-efficacy siswa dan kemampuan komunikasi matematis siswa maka, uji hipotesis penelitian yang digunakan adalah analisis regresi linier sederhana dan uji kelayakan model. Kedua uji tersebut dilakukan dengan bantuan software SPSS pada $\alpha=5 \%$. Adapun hasil output SPSS disajikan pada Tabel 1, Tabel 2, dan Tabel 3.

Tabel 1. Model Summary ${ }^{\mathrm{b}}$

\begin{tabular}{lcccc}
\hline Model & $R$ & $R$ Square & Adjusted R Square & Std. Error of the Estimate \\
\hline 1 & 0,795 & 0,631 & 0,618 & 11,33
\end{tabular}

Tabel 2. Anova

\begin{tabular}{llccccc}
\hline & Model & $\begin{array}{c}\text { Sum of } \\
\text { Squares }\end{array}$ & $d f$ & Mean Square & F & Sig. \\
\hline 1 & Regression & 6153.91 & 1 & 6153.91 & 47.96 & 0,00 \\
& Residual & 3592.76 & 28 & 128.31 & & \\
Total & 9746.67 & 29 & & & \\
\hline
\end{tabular}

Tabel 3. Koefisien regresi linier sederhana

\begin{tabular}{|c|c|c|c|c|c|c|}
\hline & \multirow[t]{2}{*}{ Model } & \multicolumn{2}{|c|}{ Unstandardized Coefficients } & $\begin{array}{l}\text { Standardized } \\
\text { Coefficients }\end{array}$ & \multirow[t]{2}{*}{$\mathrm{t}$} & \multirow{2}{*}{ Sig. } \\
\hline & & $\mathrm{B}$ & Std. Error & Beta & & \\
\hline \multirow[t]{2}{*}{1} & (Constant) & 2,85 & 7,30 & & 0,39 & 0,70 \\
\hline & Self-efficacy & 0,92 & 0,13 & 0,795 & 6,925 & 0,00 \\
\hline
\end{tabular}

Berdasarkan Tabel 3, diperoleh persamaan regresi $Y=2,85+0,92 X$. Nilai merupakan konstanta yang mempunyai arti jika tidak ada self-efficacy siswa maka nilai konsisten kemampuan komunikasi matematis siswa adalah sebesar 2,85 . Nilai koefisien regresi, artinya jika self-efficacy siswa mengalami peningkatan sebesar 1 
maka kemampuan komunikasi matematika siswa akan meningkat sebesar 0,92 . Koefisien regresi bernilai yang positif menandakan bahwa self-efficacy siswa mempunyai pengaruh yang positif terhadap kemampuan komunikasi matematis siswa. Hal ini berarti bahwa semakin tinggi self-efficacy siswa maka kemampuan komunikasi matematis siswa juga semakin tinggi. Nilai koefisien positif dapat diinterpretasikan bahwa selfefficacy berpengaruh positif terhadap kemampuan komunikasi matematis siswa.

Hasil pada Tabel 2 digunakan untuk hipotesis uji self-efficacy siswa memiliki pengaruh signifikan terhadap kemampuan komunikasi matematis siswa. Pada taraf signifikan $\alpha=0,05$ diperoleh nilai sig. sebesar $0,00<\alpha=$ $5 \%$. Artinya, self-efficacy siswa memiliki pengaruh yang signifikan terhadap kemampuan komunikasi matematis siswa. Berdasarkan Tabel 1 diketahui bahwa nilai dari $\mathrm{R}$ square (koefisien determinasi) sebesar 0,631. Hal ini dapat diartikan bahwa variabilitas kemampuan komunikasi matematis siswa dipengaruhi oleh selfefficacy siswa sebesar 63,1\% sedangkan 36,9\% dipengaruhi oleh faktor lain di luar self-efficacy siswa.

Hasil uji hipotesis dengan analisis regresi linier sederhana menunjukkan bahwa self-efficacy siswa memiliki pengaruh terhadap kemampuan komunikasi matematis siswa dengan persamaan regresinya adalah . Dengan persamaan regresi tersebut dapat dilihat bahwa koefisien regresi bernilai positifartinya self-efficacy siswa mempunyai pengaruh positif terhadap kemampuan komunikasi matematis siswa yang berarti semakin tinggi self-efficacy siswa maka kemampuan komunikasi matematis siswa juga semakin tinggi. Hasil tersebut sejalan dengan penelitian Hendriana dan Kadarisma (2019) dan Kurnia, dkk (2018) yang menunjukkan bahwa self-efficacy siswa memiliki pengaruh yang signifikan terhadap kemampuan komunikasi siswa.

Berdasarkan hasil analisis data self-efficacy siswa dan kemampuan komunikasi matematis siswa diperoleh hasil bahwa rata-rata siswa yang memiliki kemamuan komunikasi matematis tinggi juga memiliki self-efficacy yang tinggi. Hasil ini menujukkan bahwa siswa yang memiliki keyakinan yang cukup baik dalam menghadapai suatu kesulitan saat belajar matematika, berbagai situasi dan tugas saat belajar matematika, serta kemampuan dalam belajar matematika dapat memengaruhi kemampuan komunikasi matematis siswa. Hal ini sejalan dengan hasil penelitian Kurnia, Mulyana, Rohaeti, \& Fitrianna (2018) yang menyatakan bahwa siswa yang memiliki kemandirian belajar dan selfefficacy yang baik maka pencapaian kemampuan komunikasi matematis pun akan baik pula.

Berdasarkan analisis data self-efficacy diperoleh informasi bahwa mayoritas siswa memiliki keyakinan terkategori sedang jika dihadapkan dengan kesulitan dan berbagai situasi saat menyelesaikan tugas-tugas dan belajar matematika yang membuat siswa memberikan usaha yang lebih dan memandang persoalan yang dihadapi sebagai tantangan yang harus dihadapi serta tidak mudah menyerah dalam menyelesaikan tugas dan belajar matematika. Hal ini didukung oleh hasil observasi bahwa siswa mayoritas siswa memilki usaha yang cukup baik dan senantiasa mencoba dalam menyelesaikan tugas dan memahami materi saat belajar matematika. Hal itu menunjukkan bahwa perbedaan self-efficacy peserta didik terhadap matematika dapat berakibat perbedaan minat serta usaha yang dilakukan siswa dalam belajar matematika. Hal itu sejalan dengan hasil penelitian Widyastuti, dkk (2019) yang mengatakan bahwa faktor efikasi diri siswa dapat berdampak pada pemilihan perilaku dan perubahan minat siswa terhadap matematika. Sehingga perbedaan self-effcacy peserta didik akan memengaruhi kemampuan komunikasi matematis siswa. Hal ini juga didukung oleh pendapat Viktoriana (2012) mengenai karakteristik siswa yang memiliki self-efficacy tinggi dan self-efficacy rendah yang mengungkapkan bahwa siswa yang memiliki selfefficacy yang tinggi akan memberikan upaya yang tinggi pada apa yang dikerjakannya dan memelihara minat serta ketertarikannya sementara siswa dengan self-efficacy rendah cenderung merasa sulit untuk memotivasi dirinya sendiri, mengendurkan usahanya, atau menjadi terlalu cepat menyerah ketika mengalami rintangan.

Hasil analisis data kemampuan komunikasi matematis siswa juga menunjukkan bahwa mayoritas siswa memiliki kemampuan komunikasi matematis terkategori sedang. Terkategorinya mayoritas siswa mempunyai self-efficacy dan kemampuan komunikasi sedang menunjukkan bahwa terdapat pengaruh yang searah antara self-efficacy siswa terhadap kemampuan komunikasi matematis. Hal ini sejalan dengan hasil penelitian Hamidah (2012) dan Desmawati, dkk (2015) yang mengatakan bahwa semakin tinggi self-efficacy seseorang terhadap matematika, maka semakin tinggi pula kemampuan komunikasi matematiknya.

Berdasarkan pengamatan saat pelaksanaan penelitian, siswa yang memiliki self-efficacy tinggi cenderung memberikan respon yang positif dengan lebih cekatan dalam menanyakan tentang soal, mengerjakan soal yang diberikan dengan baik dan mengumpulkannya tepat waktu. Sedangkan, kebanyakan siswa yang memiliki self-efficacy rendah cenderung tidak aktif saat pembelajaran, mengerjakan soal dengan seadanya seperti hanya mengerjakan satu atau dua soal saja. Hal ini menunjukkan bahwa siswa dengan self-efficacy tinggi memiliki minat atau ketertarikan yang lebih tinggi dibanding siswa dengan self-efficacy rendah. Hal ini sejalan dengan hasil penelitian Widyastuti, dkk (2019) yang menunjukkan bahwa terdapat hubungan positif yang cukup kuat antara efikasi diri dengan minat terhadap matematika. 


\section{Kesimpulan}

Berdasarkan hasil penelitian dan pembahasan, self-efficacy siswa memiliki pengaruh yang signifikan terhadap kemampuan komunikasi matematis siswa. Siswa yang memiliki self-efficacy tinggi juga memiliki kemampuan komunikasi matematis yang tinggi. Sebesar $62 \%$ kemampuan komunikasi matematis siswa dipengaruhu oleh self-efficacy siswa, 38\% lainnya dipengaruhi oleh factor diluar self-efficacy siswa. Persamaan regresi linier yang didapat yaitu yang mempunyai arti jika tidak ada self-efficacy siswa maka nilai konsisten kemampuan komunikasi matematis siswa adalah sebesar 0,57. Jika self-efficacy siswa mengalami peningkatan sebesar 1 maka kemampuan komunikasi matematika siswa akan meningkat sebesar 0,10. Koefisien regresi bernilai positif menunjukkan selfefficacy siswa memiliki pengaruh yang positif terhadap kemampuan komunikasi matematis siswa. Semakin tinggi self-efficacy siswa maka kemampuan komunikasi matematis siswa juga semakin tinggi. Kemudian disarankan kepada peneliti lain yang akan melakukan penelitian tentang self-efficacy siswa, disarankan agar melakukan pengecekan data dengan mewawancarai guru matematika dan murid secara personal. Serta disarankan agar mengingatkan siswa Kembali mengenai tes yang akan dilakukan beberapa jam sebelum tes berlangsung.

\section{Daftar Pustaka}

Arifin, Zaenal. (2010). Evaluasi Pembelajaran. Bandung: PT Remaja Rosdakarya.

Arikunto, Suharsimi. (2011). Dasar-Dasar Evaluasi Pendidikan. Jakarta: Bumi Aksara.

Astuti, A dan Leonard. (2015). Peran Kemampuan Komunikasi Matematika terhadap Prestasi Belajar Matematika Siswa. Jurnal Formatif 2(2): 102-110. [Online]. Tersedia: https://journal.lppmunindra.ac.id/index.php/For matif/article/ view/91. Diakses pada 20 Oktober 2019.

Azwar, Saifuddin (2012). Tes prestasi, fungsi dan pengembangan pengukuran prestasi belajar. Yogyakarta: Pustaka Pelajar Offset

Bandura, A. (1997). Self-efficacy: The Exercise of Control. New york: W.H. Freeman and Company. [Online]. Tersedia: http://dl157.zlibcdn.com/dtoken/022e1d40b4f57 687 4625baleb687f35. Diakses pada 22 april 2020.

Desmawati, Mariana, R., Mulyani, S. H. (2015). Hubungan antara Self-efficacy dengan Kemampuan Komunikasi Matematis pada Siswa SMPN 2 Padang Panjang. Psyche Journal 8(2), pp 14-28.

Fachrurazi. (2011). Penerapan Pembelajaran Berbasis Masalah Untuk Meningkatkan Kemampuan Berpikir Kritis dan Komunikasi Matematis
Siswa Sekolah Dasar. Jurnal UPI Edisi Khusus No. 11 (Online). Tersedia:http://jurnal.upi.edu/file/8Fachrurazi.pdf. (21 November 2019).

Gewati, M. (2018). Kemampuan Matematika Siswa Indonesia Memprihatinkan, Solusinya? Diambil dari kompas.com: https://edukasi.kompas.com/read/2018/03/21/09 211381/kemampuan-matematika-siswaindonesia-memprihatikan-solusinya?page=all

Hamidah. (2012). Pengaruh Self-efficacy terhadap Kemampuan Komunikasi Matematis. Prosiding Seminar Nasional Penelitian Pendiidkan dan Penerapan MIPA Universitas Negeri Yogyakarta

Hendriana, H. (2014). Membangun Kepercayaan Diri Siswa melalui Pembelajaran Matematika Humanis. Jurnal Pengajaran MIPA, 19(1): 52-60. [Online].

Tersedia: http://journal.fpmipa.upi.edu/index.php/jpmipa/ article/viewFile/ 424/329. Diakses pada 22 April 2020.

Hendriana, H dan Gida Kadarisma. (2019). Selfefficacy dan Kemampuan Komunikasi Matematis Siswa SMP. JNPM (Jurnal Nasional Pendidikan Matematika) Volume 3, No. 1, Maret $2019 \quad$ [Online]. Tersedia: http://jurnal.unswagati.ac.id/index.php/JNPM/ar ticle/download/2033/1321424/329. Diakses pada 22 April 2020.

Hodanova, J \& Nocar, D. (2016). Mathematics Importance in Our Life. Proceedingsof INTED 2016 Conference 7th-9th March, 2016. Valencia, Spain.

Ihsan, Fuad. (2011). Dasar-dasar Kependidikan. Pt Rineka Cipta, Jakarta.

Inanna. (2018). Peran Pendidikan dalam Membangun Karkter Bangsa yang Bermoral. Jurnal Ekonomi dan Pendidikan 1(1), 27-33

Kemdikbud, (2018). Perubahan Atas Peraturan Menteri Pendidikan Dan Kebudayaan Nomor 59 Tahun 2014 Tentang Kurikulum 2013 Sekolah Menengah Atas/Madrasah Aliyah. [Onlone]. Tersedia: jdih.kemdikbud.go.id

Kurnia, R. D. M., Mulyani, I., Rohaeti, E. E., \& Fitrianna, A. Y. (2018). Hubungan Antara Kemandirian Belajar dan Self Efficacy Terhadap Kemampuan Komunikasi Matematis Siswa SMK. JIPMat, 3(1), 59-64. [Online]. Tersedia: http://journal.upgris.ac.id/index.php/JIPMat/arti cle/view/2183.

Lestari, Karunia Eka dan Mokhammad Ridwan Yudhanegara. (2015). Penelitian Pendidikan Matematika. PT. Refika Aditama, Bandung. 365 hlm.

Mustaqim, R. (2009). Hubungan antara Kemandirian dengan Self-Efficacy pada Mahasiswa. Unpublished Skripsi. Bandung: UPI.

Noer, Sri Hastuti. (2012). Self-efficacy Mahasiswa Terhadap Matematika. Prosiding Seminar Nasional Pendidikan Matematika. [Online]. Tersedia: http://eprints.uny.ac.id/10098/. Diakses pada 23 April 2020. 
OECD. (2018). PISA 2015 Results in Focus. (http://www.oecd.org/pisa) Diakses pada 10 November 2019.

Pusat Bahasa Depdiknas. (2016). Kamus Bahasa Indonesia (Edisi Kelima). Jakarta: Balai Pustaka. (Online). Tersedia: https://kbbi.kemdikbud.go.id/entri/pengaruh. Diakses 4 November 2019.

Simalango, Maria Mareta., Darmawijoyo, Aisyah, Nyimas. (2018) Kesulitan Siswa dalam Menyelesaikan Soal-soal PISA pada Konteks Change and Relationship Level 4, 5, dan 6 di SMPN 1 Indralaya. Jurnal Pendidikan Matematika Volume 12 Nomor 1, pp 43-58.

Siregar, Nani Restati. (2017). Persepsi Siswa pada Pelajaran Matematika: Studi Pendahuluan pada Siswa yang Menyenangi Game. Prosiding Temu Ilmiah Nasional X Ikatan Psikologi Perkembangan Indonesia 22-24 Agustus 2017, pp 224-232.

Sudijono, Anas. (2013). Pengantar Evaluasi Pendidikan. Raja Grafindo Persada. Jakarta. 471 hlm
Victoriana, Evany. (2012). Studi Kasus Mengenai SelfEfficacy Untuk Menguasai Mata Kuliah Psikodiagnostika Umum pada Mahasiswa Magister Profesi Psikologi Di Universitas "X". [Online].

Tersedia: http://repository.usu.ac.id/bitstream/123456789/ 20422/4/Chapter\%20II.pdf. Diakses pada 23 April 2020

Widyastuti, Agung P.W., Wayam R., dan Rini R.T.M. (2019). Minat Siswa terhadap Matematika dan Hubungannya Dengan metode Pembelajaran dan Efikasi Diri. Jurnal Pendidikan Matematika Volume 13, No. 1. [Online]. Tersedia: https://ejournal.unsri.ac.id/ index.php/jpm/article/view/6750. Diakses pada 24 Agustus 2020

Wulansari, Suganda, Asep Ikin., Fitriana, Aflich Yusnita. (2019). Hubungan Self-Efficacy terhadap Kemampuan Berpikir Kreatif Matematik Siswa SMP pada Materi Bangun Datar Segitiga dan Segiempat. Jurnal on Education Volume 01 Nomor 03, pp 422-428 